\title{
The Advocate
}

Volume 23

Number 3 Fall - Winter 2017

Article 2

$12-1-2016$

\section{When Study Abroad Is Not Enough: Improving Language Proficiency through Virtual Interaction}

Christopher J. Jochum

Ft. Hays State University

Follow this and additional works at: https://newprairiepress.org/advocate

Part of the Teacher Education and Professional Development Commons

\section{Recommended Citation}

Jochum, Christopher J. (2016) "When Study Abroad Is Not Enough: Improving Language Proficiency through Virtual Interaction," The Advocate: Vol. 23: No. 3. https://doi.org/10.4148/2637-4552.1023

This Research Article is brought to you for free and open access by New Prairie Press. It has been accepted for inclusion in The Advocate by an authorized administrator of New Prairie Press. For more information, please contact cads@k-state.edu. 


\title{
When Study Abroad Is Not Enough: Improving Language Proficiency through Virtual Interaction
}

\begin{abstract}
The purpose of this study was to investigate the experiences of an in-service Spanish teacher who, despite studying abroad on multiple occasions, was unable to meet the proficiency requirements necessary for professional licensure in her state. Using a single case study design (Yin, 2014), the author documented the year-long experiences of this teacher as she engaged in virtual language activities with a Native Spanish speaker to successfully improve her proficiency. The following paper will provide a brief overview of the study, the supporting theoretical framework, methods, results and scholarly contributions to the field of foreign language education and teacher preparation.
\end{abstract}




\title{
When Study Abroad Is Not Enough: Improving Language Proficiency through Virtual Interaction
}

\section{Christopher J. Jochum}

\section{Ft. Hays State University}

\begin{abstract}
The purpose of this study was to investigate the experiences of an in-service Spanish teacher who, despite studying abroad on multiple occasions, was unable to meet the proficiency requirements necessary for professional licensure in her state. Using a single case study design (Yin, 2014), the author documented the year-long experiences of this teacher as she engaged in virtual language activities with a Native Spanish speaker to successfully improve her proficiency. The following paper will provide a brief overview of the study, the supporting theoretical framework, methods, results and scholarly contributions to the field of foreign language education and teacher preparation.
\end{abstract}

When Study Abroad Is Not Enough: Improving Language Proficiency through Virtual Interaction

The purpose of this study is to present initial findings from a case study designed to document and better understand the experiences of Laura*, a in-service Spanish teacher who, after completing a summer study abroad experience, was unable to attain minimum proficiency ratings on the American Council on the Teaching of Foreign Languages (ACTFL) Oral Proficiency Interview (OPI) and Writing Proficiency Test (WPT), which was required to achieve permanent teaching licensure in her state, thus enabling her to maintain employment as a foreign language educator. Determined to improve her Spanish proficiency, and remain in her current teaching assignment, Laura engaged in a year-long process of virtual activities with a Native Spanish Speaker which ultimately resulted in her achieving the required proficiency levels and attaining licensure as a Spanish educator.

Theoretical framework

This study was based on the need for foreign language teachers' to attain minimal levels of advanced language proficiency to be effective in the classroom. The 
ACTFL / CAEP (Council for the Accreditation of Educator Preparation) Program Standards for the Preparation of Foreign Language Teachers (2013) suggests a minimum proficiency level of Advanced-Low (AL) for Spanish teachers (p. 15). Additionally, The National Board for Professional Teaching Standards also requires foreign language teachers to "exemplify a high proficiency in the languages they teach" (2010, p. 21). As Moeller (2013) states "Teachers below the AL of oral proficiency are typically, at best, 'textbook teachers' who need the answer key in order to function in the classroom" (p. 550). However, attaining Advanced-Low proficiency can be difficult as it requires at least 720 hours of formal instruction in the foreign language (Liskin-Gasparro, 1982; Malone, Rifkin, Christian, \& Johnson, 2005). While the connection between studying abroad and advanced language proficiency is well documented (Brecht, Davidson \& Ginsberg, 1995; Freed, 1995; Schmidt-Rinehart \& Knight, 2004; Segalowitz \& Freed, 2004; Swender, 2003), there is a need to better understand and articulate the process individuals take when trying to improve their language skills either in the absence of study abroad or when spending time in the target culture is not enough.

Methods

\section{Design}

A single case study design (Yin, 2014) was used to better understand how engaging in virtual language activities with a Native Spanish speaker contributed to Laura's increased proficiency. The study took place between 2014 and 2015 under the direction of the author, which was important as it provided the opportunity to interact with Laura and engage in continued conversations as she progressed toward her goal. After previous failed attempts of reaching Advanced-Low status ( on both Oral Proficiency Interview and Writing Proficiency Test), which also including spending a month studying abroad in a Spanish-speaking country, the author employed a prescriptive analysis for Laura which involved engaging in the target language (i.e. Spanish) with a native speaker on a weekly basis. Some of this activities included online conversations, email exchanges, informal text messages and interacting through social media.

\section{Participant}

Purposeful sampling (Creswell, 2012) was used to select the participant based upon her (a) participation in a summer study abroad program during the summer of 2014; (b) employment as a conditionally certificated Spanish teacher in the United States; (c) previous OPI and WPT scores of Intermediate-High; and (d) need to attain Advanced-Low ratings on the OPI and WPT to become fully certificated in her state. At the time of the study, Laura was a 26 year old female who had been teaching secondary Spanish for three years on a temporary state credential. Despite having 
spent a total of seven months living in a Spanish speaking country as an undergraduate, Laura failed to reach minimum levels of speaking and writing proficiency on three occasions during her first two years of teaching.

\section{Data Sources}

Multiple data sets were used to analyze Laura's experiences engaging in virtual language interactions in order to improve her proficiency and achieve professional teaching certification which included: (a) participant interviews; (b) researcher observations; and (c) a participant reflection journal. The primary data source was semi-structured interviews (Seidman, 2012), which occurred throughout the year as Laura worked to improve her proficiency ratings. Questions were developed based upon a review of the relevant literature as well as the expertise of the author. Follow-up interview questions were related to the initial interview questions but modified based upon Laura's previous responses. The initial interview protocol appears in Appendix A.

\section{Results}

The purpose of this single case study was to better understand the experiences and factors that contributed to an in-service Spanish teacher's (Laura), ability to improve her language proficiency as a result of engaging in virtual language activities with a Native Spanish speaker. Data analysis revealed that Laura experienced a great deal of personal, intellectual and professional growth as a result of her year-long efforts to improve her Spanish and ultimately keep her teaching position. The following will offer a cursory overview of the findings.

At the start of the study, Laura was very discouraged and was contemplating leaving the teaching profession as previous attempts at the OPI and WPT both resulted in ratings of Intermediate-High, which was one level below the required minimum of Advanced-Low. In one of our initial interviews she expressed her fear and frustration by commenting that the proficiency exam was "the one thing standing between me and my profession" and that "I know my career in on the line". Determined to improve her proficiency, Laura enrolled in a graduate-level summer study abroad program in which she spent four weeks in an intensive language program in Costa Rica. Within ten days of completing this program, Laura once again took the OPI and WPT but remained at the Intermediate-High level. With her confidence and self-efficacy waning, the author of this study connected Laura with Esperanza*, a Native Spanish-speaking graduate assistant. Because Laura and Esperanza were located in separate parts of the country, a protocol was developed that enabled them to engage in a series of virtual, weekly activities in Spanish, which included online conversations (Skype), email exchanges and sending each other informal text messages. Laura's reflection journal as well as semi-structured interviews during this time reveal that she was feeling a renewed sense 
of confidence as she engaged in these post-study abroad activities. In addition, she indicated that her self-efficacy as a foreign language teacher was higher than previously reported. This was revealed in one of our first interviews after she had spent a month engaging in various linguistics tasks with Esperanza when she said "I'm not stressed speaking Spanish with her because we're the same age and I know she understands what it's like to learn another language. In addition, I know she's not evaluating my language all the time". This year-long process was truly transformative for Laura as she ultimately reached the Advanced-Low levels on the OPI and WPT. This not only affected her confidence and longevity as a teacher but also improved her proficiency and enabled her to enhance her instructional practice. When asked how her confidence had changed as a result of passing the licensure exams, Laura said "I'm more confident in my teaching and was even assigned an advanced Spanish course for the upcoming school year".

\section{Scholarly Contribution}

While this study is limited to a single case or participant, the results nonetheless represent a significant contribution to the field of foreign language education, especially as it relates to the development of language proficiency among pre and in-service foreign language educators. Findings revealed that while studying abroad is a necessary component for achieving advanced proficiency (Swender, 2003), individuals may still need to engage in post-study abroad language activities to reach their proficiency goals. In addition, this study suggests a model of virtual language development which is often times necessary for those who are place-bound, without face-to-face access to Native Spanish speakers. Finally, the results of this study support the connection between foreign language teachers' language abilities and self-efficacy (Chacón, 2005; Yilmaz 2011), which ultimately affects their students' achievement (Swanson, 2014). Laura best exemplified the value improving her proficiency through engaging in virtual activities with the following: "I feel like I belong and I know my school trusts me now".

*Pseudonyms were used to ensure confidentiality. 


\section{References}

American Council on the Teaching of Foreign Languages. (2013, August).

ACTFL/CAEP program standards for the preparation of foreign language teachers. [Electronic version]. Retrieved from http://www.actfl.org/sites/default/files/pdfs/ACTFL-Standards20Aug2013.pdf

Brecht, R. D., Davidson, D. E., \& Ginsberg, R. B. (1995). Predictors of foreign language gain during study abroad. In B. F. Freed (Ed.), Second language acquisition in a study abroad context (pp. 37-66). Amsterdam: John Benjamins Publishing.

Chacón, C. T. (2005). Teachers' perceived efficacy among English as a foreign languages teachers in middle schools in Venezuela. Teaching and Teacher Education, 21(3), 257-272.

Creswell, J. W. (2012). Qualitative inquiry and research design: Choosing among five approaches. ( $3^{\text {rd }}$ ed.). Thousand Oaks, CA: Sage.

Freed, B. F. (1995). What makes us think that students who study abroad become fluent? In B. F. Freed (Ed.), Second language acquisition in a study abroad context (pp. 123-148). Amsterdam: John Benjamins Publishing.

Liskin-Gasparro, J. E. (1982). ETS Oral Proficiency Testing Manual. Princeton, N. J.: Educational Testing Service.

Malone, M., Rifkin, B., Christian, D., \& Johnson, D. (2005). Attaining high levels of proficiency: Challenges for foreign language education in the United States. CAL Digests.

Moeller, A. J. (2013). Advanced low language proficiency: An achievable goal? The Modern Language Journal, 97(2). 549-553.

National Board for Professional Teaching Standards. (2010). NBPTS World language Standards. (2nd ed. Retrieved from http://boardcertifiedteachers.org/sites/default/files/ECYA-WL.pdf

Schmidt-Rinehart, B. C., Knight, S. M. (2004). The homestay component of study abroad: Three perspectives. Foreign Language Annals, 37(2). 254-262.

Segalowitz, N., \& Freed, B. F. (2004). Context, Contact, and Cognition in Oral Fluency Acquisition: Learning Spanish in At Home and Study Abroad Contexts. Studies In Second Language Acquisition, 26(2), 173-199. 
Seidman, I. (2012). Interviewing as qualitative research: A guide for researchers in education and the social sciences $\left(4^{\text {th }}\right.$ ed.). New York: Teachers College Press.

Swanson, P. (2014). The power of belief: Spanish teachers' sense of efficacy and student performance on the National Spanish Examinations. Hispania 97(1), 5-20.

Swender, E. (2003). Oral proficiency testing in the real world: Answers to frequently asked questions. Foreign Language Annals, 36(4). 520-535.

Yin, R. K. (2014). Case study research: Design and methods (5th ed.). Thousand Oaks, CA: Sage Publications. 
Appendix A

Interview Protocol

1. What is your name?

2. What is your age?

3. How many years have you been teaching Spanish?

4. When, where and for how long did you study abroad?

5. Do you feel as though your study abroad experience(s) met your proficiency needs?

6. What was your initial score on both the OPI and the WPT?

7. How did you feel when you received your first OPI and WPT scores? Did this affect your self-efficacy as a teacher?

8. What are you doing on a weekly basis to improve your speaking and writing skills in Spanish?

9. Do you feel confident that you will obtain your teaching license?

10. Do you feel confident in your abilities to effectively teach your students Spanish?

11. Do you feel as though your undergraduate program effectively prepared you to meet the proficiency demands required for licensure?

12. Are you experiencing any stress as a result of working to improve your proficiency in order to obtain your teaching license? 